\title{
Food habits of rural Swazi households: 1939- 1999 Part 1: Technological influences on Swazi food habits
}

\author{
Mmantoa S Kgaphola \& Annemarie T Viljoen
}

\section{OPSOMMING}

Hierdie artikel bied basiese inligting oor die eetgewoontes van landelike Swazi-huishoudings. Dit bevat ' $n$ oorsig van die literatuur in verband met Swazi-eetgewoontes gedurende die afgelope ses dekades asook die bevindings van 'n gevallestudie oor die eetgewoontes van tien geselekteerde Swazi-huishoudings in Ka-Mantsholo in die Badplaasdistrik.

Hamilton se model (1987) vir die drie komponente van kultuur, naamlik tegnologie, sosiale struktuur en ideologie, is vir die teoretiese raamwerk gebruik. Die gepubliseerde literatuur asook die bevindings van die gevallestudie dui daarop dat die beskikbare tegnologie ' $n$ invloed op die tradisionele asook die huidige eetgewoontes van landelike Swazi-huishoudings uitgeoefen het. Die bevindings van die gevallestudie dui op akkulturasie met betrekking tot die eetgewoontes van hierdie groep huishoudings, veral ten opsigte van die aanvaarding en insluiting van sekere Westerse voedselsoorte en voedselbereidingstegnieke. Ten spyte van akkulturasie vorm tradisionele Swazi-geregte wat van inheemse gewasse en veldplante berei word, egter steeds ' $n$ belangrike komponent in die Swazi dieet. Tradisionele voedsel en voedselbronne behoort dus in voedselsekuriteitsprogramme ingesluit te word. Op sy beurt bepaal die beskikbare tegnologie die beskikbaarheid en verbruik van hierdie voedsel.

\section{- Ms MS Kgaphola}

- Mrs AT Viljoen

Department of Consumer Science

University of Pretoria

\section{INTRODUCTION}

The purpose of this article is to establish baseline data on the current food habits of selected rural Swazi households in the southern Highveld region of the Mpumalanga Province for use in household food security projects. No prior studies have been done in this area, and no baseline information is available as a basis for food security and nutrition-related projects.

This article presents a literature review and a case study among ten selected rural Swazi households at Ka-Mantsholo in the Badplaas district (between Badplaas and Barberton). The village is one of Land Affairs' land redistribution projects and is a new settlement near the border of Swaziland and South Africa. The literature review is based on a limited number of documented studies on food habits in Swaziland (Beemer, 1938; Jones, 1963; Ogle \& Grivetti, 1985). These publications were the only published sources of information the authors could find on traditional food habits of the Swazi people.

The main aim of the case study (Kgaphola \& Viljoen, 1999) was to determine the current food habits of ten selected Swazi-speaking rural households so that the information could be compared with the available literature on the Swazis. Data were collected by means of a structured interview schedule. Questions were asked on aspects such as food cultivation and acquisition, food preparation methods and facilities, and meal patterns. Information on food avoidance and food consumption on special occasions was obtained to establish whether traditional beliefs and customs were still practised. A food frequency list was compiled as a cross-check for meal patterns and to determine how familiar the participants were with traditional and Western foods and how often these foods were consumed.

Ten ladies from a woman's club at Ka-Mantsholo (between Badplaas and Barberton) volunteered to participate in the case study (Kgaphola \& Viljoen, 1999). In eight of the ten households the housewives were responsible for food preparation, and in the other two a daughter-in-law and a daughter prepared the food. Seven of the respondents had attended school and the other three had received no formal education. Of the seven respondents who had attended school, one had acquired a Grade 9 qualification and the others had Grade 7 or lower qualifications. The households ranged from four to ten mem- 
bers per household. This household size is similar to that reported by Ogle and Grivetti (1985b) for households in Swaziland. Most of the participants indicated that they belonged to the Christian faith.

The available documentation on Swazi food habits will be presented together with the findings from the case study (Kgaphola \& Viljoen, 1999). Part 1 reports on technological influences on Swazi food habits, and Part 2 deals with the impact of social structure and ideology on Swazis food habits. Hamilton's model (Hamilton, 1987) on the three components of culture is used as a frame of reference to present the information from the literature review and the case study.

Culture is generally accepted as the nonbiological means by which humans adapt to the environment. Taylor in Hamilton (1987) describes culture as a complex whole that encompasses knowledge, beliefs, art, morals, law, custom and other capabilities and habits acquired by man as a member of society. Food is part of culture, and food habits are also influenced by culture. Mead and Guthe in De Garine (1972) defined food habits as the means by which individuals or groups select, consume and utilise portions of the available food supply in response to social and cultural pressures. Fieldhouse (1995) stated that food habits develop and are maintained because they are effective, practical and meaningful behaviours in a particular culture.

The model based on cultural anthropology developed by Hamilton (1987) as a unifying metatheory for dress, is also appropriate in describing food habits. Similar to dress, food habits may be considered a subsystem of the macrocultural system, as they are also based on the three primary and interrelated subsystems of culture, namely technology (material culture), social structure (social behaviour), and ideology (beliefs, attitudes and values). Hamilton's model (Hamilton, 1987) rests on the assumption that culture is a dynamic, interacting and changing system. Food habits have also been described as dynamic (Fieldhouse, 1995:1), and Hamilton's model is therefore appropriate for a study of food habits.

In addition to being dynamic, culture is systematic because the different parts or components are interrelated, interdependent and interactive. These components cut across the mechanisms by means of which human groups organise themselves to adapt and survive. These mechanisms include the economical, political, family/kinship, socialisation, ideological, arts and aesthetics, and communication organisation of society (Hamilton, 1987). Each mechanism has a technological, socially structural and ideological dimension and represents the nonbiological cultural solutions to problems associated with human survival and adaptation.

The contribution of the technological component of culture to changes observed in the Swazi people's food habits is highlighted.

\section{TECHNOLOGY}

Technology refers to the knowledge and tools used by man to manipulate his environment in order to meet various social needs (Popenoe, 1983:573). Soemardjan (1985:163) regards technology as the art of utilising natural and human resources to meet society's needs. According to Hamilton (1987), technology refers to the physical and social environments, and how they are organised for use in the cultural system. The same author regards technology as the main interface between culture and nature. White in Hamilton (1987) states that the technological factor determines social systems, and that technology and society together determine the content and orientation of philosophy or ideology. Technology plays a role in most activities related to food behaviour, including food production, processing, storage, preparation or manipulation, serving and eating.

Food technology is as old as food behaviour itself. As indicated above, man uses technology to adapt and modify his environment. This is clearly illustrated by the manner in which humans use technology to satisfy their food and nutritional needs (Jerome et al, 1980:13-40; McIntosh, 1995:43-46). The natural environment as well as the available technology influences the availability of food in that the natural environment determines the type of plants and animals in a given geographical area, and technology determines the extent to which a given natural environment may be exploited to produce food. Improved transport systems, processing and preservation equipment and techniques have all contributed to increased food availability in geographical zones where it was previously unavailable.

The impact of technology on Swazi food habits is addressed under the following headings: acquisition of food, available food, food storage and preservation, food preparation and food preparation techniques.

\section{Acquisition of food}

The technological environment of the Swazis has not developed extensively, and therefore their traditional diet was greatly influenced by the natural environment (Beemer, 1939). What was traditionally cultivated in Swaziland, depended on the geographical region.

Swaziland may be divided into four different geographical regions, namely Highveld, Middleveld, Lowveld and Lebombo. Each of these regions has a distinctive climate, rainfall and geography (Jones, 1963; Ogle \& Grivetti, 1985a). Jones (1963), in her study on Swazi nutrition, indicated that food availability was seasonal and the seasons consequently dominated the life and food habits of rural Swazis. Food shortages at the end of winter were stoically accepted and even considered inevitable (Jones, 1963:45). Food was plentiful from January to March when an abundance of fresh mealies, pumpkins, green vegetables and legumes were available. From September 
until December, when the first maize ripened, food was scarce.

There were periods of feast when food was plentiful, and periods of famine when there were serious food shortages. The agricultural potential was not maximally exploited because primitive agricultural equipment and techniques were used. Improved food availability depended on equipment as well as adequate and effective storage facilities. Many households had no access to either for economic reasons. Agricultural activities were very labour-intensive and the heaviest work had to be done when food supplies were limited (Jones, 1963:45).

The Swazis traditionally supplemented their diet of cultivated food with leafy vegetables and fruits from the veld. The older generation knew about edible natural foods and had the skills to recognise climatically adapted food sources to supplement their food supplies (Ogle \& Grivetti, 1985a). The case study under discussion found that the natural environment still had an extensive influence on such supplementary foods for rural Swazi households (Kgaphola \& Viljoen, 1999). All the respondents indicated that they gathered food in the veld, depending on availability. However, their current residential areas had fewer sources of uncultivated food than where they lived before resettlement. Hunting has declined due to the scarcity of wild animals. All the participants reported that they gathered uncultivated leafy vegetables in the spring, summer and autumn. The common plants included chuchuza (Biddens bipinnata), igushe (Corchorus confusus) and imbuya (Amaranthus hybridus). Ogle and Grivetti (1985b) also reported the gathering of these species. Six of the participants said they gathered wild fruit in summer and autumn.

The Swazis traditionally had several food sources, namely agriculture, hunting and gathering. They also acquired food through gifts and bartering. When they were introduced to the cash economy, two other sources of food became available, namely purchasing and rations from employers. Over the years the Swazi people moved from a position of shifting cultivators to people who lived semipermanently at semisubsistence level where food supplies were augmented by the wages unskilled and semiskilled labourers earned in industry (Jones, 1963:41).

The results of this recent case study are similar to the findings of Ogle and Grivetti (1985b), indicating that rural Swazi households are still semisubsistence farmers who augment their homegrown food supply with purchased food. Even during good years with good harvests, they still have to augment their homegrown food with purchased food. (See Table 1 on food acquisition methods reported in the case study (Kgaphola \& Viljoen: 1999).)

All the participants reported that they bought most of their food at either supermarkets in nearby towns or at local shops. Only two participants reported that they bought solely from the local shops. Eight participants said that they bought mainly once per month, and two indicated that they bought their supplies twice per month. Nonperishable food items were bought once or twice per month, and perishable foods were bought more frequently. Bread is for instance bought daily, and meat and milk are bought when needed. Similar to findings of Jones (1963:59), most of the housewives in the study reported that they decided about purchasing and cooking, and only one reported that the whole family decided on such matters.

\section{Available food}

Cereals The traditional Swazis lived on what the natural environment had to offer, similar to other black ethnic groups in Southern Africa. Their most important staple cereals were sorghum (Adropogon sorghum) with millet (Pennissetum spicatum) and later maize (Zea Mays) (Beemer, 1939; Jones, 1963:68; Coetzee, 1982:67). The case study by Kgaphola and Viljoen (1999) indicated that maize and bread formed an integral part of the rural Swazi diet. The ten rural households in the case study reported that maize was their staple cereal. They also included rice in their diet.

Vegetables Green leafy vegetables formed an essential part of the traditional Swazi diet and were especially valued when other supplements to maize (which became the staple cereal) were exhausted (Jones, 1963:69). These vegetables included cultivated indigenous and uncultivated crops that grew in the veld. According to Beemer (1939), the Swazis actually cultivated very few green vegetables, for example leaves of pumpkin and cowpeas and in some areas the leaves of amadume (colocasia antiquorum) and sweet potatoes.

In addition to the leafy vegetables, a variety of Cucurbits were cultivated, for example pumpkins, melons and gourds, and were usually planted among the maize (Beemer, 1939; Jones, 1963:70). Jones (1963:69) reported that yellow and white sweet potatoes were cultivated and that the latter were very popular. Several varieties of wild roots and tubers were collected and eaten at the end of summer and during the winter months (Jones, 1963:69).

Jones (1963:69) and Ogle and Grivetti (1985b) indicated that certain European vegetables, for example onions, cabbage and tomatoes, were becoming a popular part of the Swazi cuisine. These researchers respectively added potatoes and spinach to the list. The case study by Kgaphola and Viljoen (1999) showed that most of the participants cultivated vegetables such as carrots, cabbage, spinach, beetroot, tomatoes, potatoes, onions, peppers, chillies, okra and pumpkins. As reported by Beemer (1939), all the respondents in this study also said they cultivated pumpkins and cowpeas for their leaves. Other indigenous vegetable crops included tubers such as sweet potatoes and roots such as amadumbe (Colocasia antiquorum). 
TABLE 1: FOOD ACQUISITION METHODS OF TEN RURAL SWAZI HOUSEHOLDS IN KA-MANTSHOLO (Kgaphola \& Viljoen, 1999)

\begin{tabular}{|l|c|}
\hline \multicolumn{1}{|c|}{ Method of acquisition } & $\begin{array}{c}\text { Number of } \\
\text { households }\end{array}$ \\
\hline Purchasing of food & \\
\hline Supermarkets and local shops & 2 \\
\hline Local shops only & 2 \\
\hline Shopping frequency & 8 \\
\hline Mainly once a month & 2 \\
\hline Mainly twice a month & \\
\hline Own production & 9 \\
\hline Maize & 10 \\
\hline Indigenous vegetables and fruit & 9 \\
\hline Vegetables & 8 \\
\hline Poultry & 3 \\
\hline Cattle & 3 \\
\hline Goats & \\
\hline Gathering from the veld & 10 \\
\hline Leafy vegetables & 6 \\
\hline Wild fruit & 2 \\
\hline Locusts & 10 \\
\hline Fish & 3 \\
\hline Game & \\
\hline
\end{tabular}

The study by Kgaphola and Viljoen (1999) showed that cultivated and uncultivated leafy vegetables formed part of the daily meals of the ten rural Swazi households who participated in this case study.

Legumes A wide variety of legumes were cultivated, for example mung beans, jugo beans cowpeas, and peanuts (Beemer, 1939; Jones, 1963:69). In addition to the indigenous legumes, Kgaphola and Viljoen (1999) reported that other legumes such as sugar and butter beans had been adopted.

Fruits According to Beemer (1939), fruit collected from indigenous trees and plants was used to supplement the cultivated crops of the Swazis. Jones (1963) also documented this practice nearly 30 years later. She indicated that wild fruit was mainly eaten as a snack and that the custom to plant fruit trees had just been introduced. The most popular fruit trees were paw-paws, mangoes, peaches, citrus and bananas (Jones, 1963:70). The participants in the case study by Kgaphola and Viljoen (1999) indicated that the Swazi ate wild fruit such as amakwakwa (monkey orange), umfofo (quinine berry) and mganu (merula fruit) and cultivated fruit such as oranges, guavas, bananas, and apples. Since the participants had recently been resettled in this area, they did not all have fruit trees and wild fruit was unavailable as they had been resettled on land that used to be a commercial farm.

Meat and meat products Cattle were traditionally a symbol of wealth and were not kept for food purposes. Cattle were only slaughtered on religious and ceremonial occasions. A carcass was divided according to culturally prescribed rules for different age and gender groups (Beemer, 1939; Jones, 1963:72-73). Sheep, goats and chickens were used for food. Pigs were kept, but pork was reported as not popular because it was said to cause vomiting (Jones, 1963:71). Beemer (1939) reported that certain parts of Swaziland were rich in game that was used as a food source, especially during the winter months. Sheep and goats were considered the poor man's cattle and were frequently slaughtered for food (Beemer, 1939).

Eight of the participants in the case study by Kgaphola and Viljoen (1999) had livestock and all reported that they used it as food. The livestock included cattle, goats and chickens. All the respondents indicated that they used chicken as food more than once a month. Of the eight participants who said they kept livestock, only three said they used cattle and goats as food for special occasions such as weddings, ancestral worshipping and family gatherings. Cattle were also slaughtered when they were old or when the head of the household wanted to generate income by selling meat. The participants in the case study by Kgaphola and Viljoen (1999) reported that game and birds used to be available, but after the move to the Badplaas area only three participants had access to game.

Insects Caterpillars, termites and locusts were reported to be seasonal delicacies (Beemer, 1939; Jones, 1963:72) that were usually fried. Some of these insects were becoming scarce and the women who were interviewed reported that although they still enjoyed eating them, their children frown upon this type of food (Kgaphola \& Viljoen, 1999). The respondents said they all used to gather locusts, but since the resettlement in the Badplaas area, only two reported to have hunted for locusts. Although all knew that caterpillars were edible, the majority did not eat them.

Eggs Only the men ate hen's eggs. The belief was that women who ate eggs would lust after men, and girls were forbidden to eat eggs after puberty (Jones, 1963:74). The case study by Kgaphola and Viljoen (1999) showed that eggs formed part of the Swazi cuisine and no restrictions were mentioned in this regards. This suggests that the taboo on eggs for girls after puberty was not strictly imposed or was no longer common.

Fish Fish was not considered a food source as hey believed that fish was closely related to snakes (Jones, 1963:74). As Ogle and Grivetti (1985a) indicated, this taboo was no longer strictly observed because canned pilchards, sardines, and fish and chips were regularly consumed as a side dish. Kgaphola and Viljoen (1999) reported that both fresh fish and tinned fish formed part of the cuisine of the ten households that were studied. These households all reported that they fished in a dam close to their homes, and they identified tinned fish as a food item they bought in bulk because it did not require refrigeration. 
Milk and milk products Food products from cattle were treated with ceremony and respect on all occasions (Jones, 1963:74). The cows were milked twice per day, and everyone preferred the soured form (emasi). Specific rules applied to the consumption of emasi (Jones: 1963:75-76). Goats and donkeys were not milked. Both fresh and soured milk was still regarded an essential component of the Swazi diet.

Fat and oil Fat and oil were traditionally used minimally in food preparation. Beemer (1939) reported that pigs were mainly kept for their fat, but made no mention of whether the fat was used in food preparation. However, Jones (1963:76) reported increased utilisation of fats and oil in food preparation. Kgaphola and Viljoen (1999) also reported such an increase.

\section{Food storage and preservation}

Cereals Jones (1963:48-49) observed that the storage and preservation methods for cereals were not very sophisticated. The best maize cobs were dried and kept for seed. They were kept with sorghum heads in the thatched roof of the kitchen. The smoke from the open fire prevented pests from attacking the grain. The rest of the grains were for household consumption. Large quantities were stored in an underground granary or pit called an ingungu that was built in the cattle kraal. The pit was bottle-shaped, narrow at the neck and approximately ten feet wide at the base. Although precautions were taken, water or dampness caused mould to develop. The mouldy grain had an unusual flavour. The older generation liked their porridge with this flavour but the younger generation did not like the taste (Beemer, 1939; Jones, 1963:49). The maize for immediate household use was temporally stored in grass baskets, sacks and other receptacles and kept in storage huts or in the kitchen. Nine participants in the case study by Kgaphola and Viljoen (1999) reported that they dried their maize.

Vegetables and fruit Cultivated and wild vegetables were cut into small pieces and spread on a flat surface to dry in the sun (Beemer, 1939). In the evenings and on windy days the vegetables were brought indoors until they were dry. Sometimes the vegetables were blanched before they were dried, but this method was unpopular because the original taste and colour changed. Pumpkins and melons were peeled, seeded and cut into segments and dried. The studies by Jones (1963:48) and Ogle and Grivetti (1985c) also made mention of the drying of leafy vegetables.

Eight of the participants in the case study by Kgaphola and Viljoen (1999) reported that they sun-dried their leafy vegetables. All the participants reported that they cultivated vegetables. With the exception of pumpkin leaves, no preservation of any other cultivated vegetables was mentioned. It was not established why other vegetables were not preserved. Certain wild fruits were allowed to dry in the picked state. It was a common practice to dry vegetables and fruit for use during lean months (Jones, 1963:48).

Legumes Peanuts and jugo beans were sometimes stored in the granaries; otherwise they were stored in bags or baskets in the food hut (Beemer, 1939). Kgaphola and Viljoen (1999) reported sun drying of legumes as a common practice of rural Swazi households.

Meat Cattle were only occsionally slaughtered, and then the meat was divided and eaten within the next day or two (Beemer, 1939; Jones, 1963:72-73). The available literature on the traditional eating patterns of the Swazis made no mention of the preservation of meat. In the case study by Kgaphola and Viljoen (1999), however, five participants reported that they dried red meat if they had it in abundance, but the majority said they seldom had meat in abundance to preserve.

\section{Food preparation}

Food preparation facilities Food was either cooked inside the kitchen hut called the lidladla, or outside if the weather permitted. The hearth was a circular depression in the centre of the hut floor. A piece of iron sheet was used to line the hearth. An iron tripod or three stones were used to support the cooking vessels. Outdoor hearths were similar in construction, and were protected against the wind by a reed screen that enclosed the hut yard (Jones, 1963:64).

All the participants in the Kgaphola and Viljoen (1999) case study reported that they cooked in the kitchen, mainly by using a coal stove. Four of the participants reported that they also used a primus stove, and the other two used an open fire for preparing items such as tea or soft porridge. Jones (1963:63) also reported the use of primus stoves for quick dishes in urban Swazi households. Wood still seemed the preferred fuel for cooking. Paraffin was the next most common source of energy, and gas the least common.

The influence of technology on the food habits of the ten rural Swazi households who participated in the case study was evident from the effect food preparation facilities had on meal patterns and cold storage facilities had on the availability of food for the household. Although all the households reported that they had three meals per day, the majority said they tried to save fuel by reducing the frequency of cooking. A large quantity of food was prepared once during the day and the leftovers were served in the evening to save wood.

Few of the participants had cold-storage facilities and they were therefore unable to buy perishable foods such as meat, milk, cheese, margarine or butter in bulk. Instead they were forced to buy tinned foods, which they did not like, because it kept well. All the participants reported that they drank tea and coffee with coffee creamers because they did not have the means to store fresh milk. Peanut butter and jam 
were used as spread on bread, and margarine was only used in winter because it kept better in colder weather. These results emphasised how available resources and technology influenced food habits.

\section{Utensils for food preparation According to Jones (1963:65), clay pots were traditional Swazi cooking vessels. The clay pots were also used to fetch and store water and to brew beer. The clay pots had certain disadvantages, however, the biggest of which was that the lids did not fit well. Closely wrapped green leaves were used to improve the fit. Another disadvantage was that the clay pots broke easily and Swazi housewives therefore began using three-legged iron cooking pots. These heavy iron pots had close-fitting lids and were used for all cook- ing processes except for mixtures that bubbled exces- sively.}

Wooden spoons of various sizes were used to stir the food. The lujojo, which closely resembles the European swizzle stick, was used to mix maize meal into the boiling water. A variety of utensils such as scoops, ladles and dishes were made by shaping the fruits of the gourd.

A whole gourd was used as a calabash (vessel) in which milk was ripened for the soured milk emasi . This calabash for the preparation of emasi had a hole in the bottom that was plugged with the skin of a special root. When the emasi was ripe, the whey was drained through the base of the calabash (Jones, 1963:66)

The men and boys carved the traditional meat serving dishes from two-coloured wood. These dishes were round and stood on short legs (Jones, 1963:65). Jones (1963:65) observed that Western-type food preparation and serving equipment were gradually introduced into some Swazi households. She mentioned the use of enamelled, iron and aluminium saucepans in urban areas for use on paraffin stoves. Other "modern" containers for serving food were enamelled iron or aluminium dishes and china plates.

\section{Food preparation techniques}

The first task in food preparation, apart from wood and water collection, was to grind the maize. The sorghum and maize grains were hand-ground with two stones before the meal was prepared. This grinding process was tedious and time-consuming (Beemer, 1939). Therefore only sufficient maize was ground for one meal and many women ground twice a day (Jones, 1963:80). The upper grinding stone was oval in shape, small and convex. The bottom one was rectangular in shape, relatively big compared to the upper stone, with a rough surface. The top surface of the bottom stone was re-hammered when it became smooth from the grinding process. Grass mats were used to receive the maize meal expelled by the grinding action. Some households sifted the maize meal after grinding by using a wire mesh sieve in a wooden frame (Jones, 1963:64). Jones (1963:80) reported that the fortunate households had hand mills and that the children assisted in the grinding process by turning the wheel of the hand mill.

Maize was prepared in various ways. Ogle and Grivetti (1985a) identified twenty-four different, clearly defined recipes for maize preparation. Porridge could be prepared in different consistencies and each consistency had a name. A large pot of water was put to the boil, a generous amount of salt was added, and grounded maize was sprinkled on top and whisked with a wooden swizzle stick. The lid was replaced and the fire was then carefully controlled to cook the porridge slowly (Jones, 1963:81).

Cooking the vegetable relish was carefully timed so that it was ready by the time the porridge was ready to be served. The relish was prepared from cultivated and uncultivated leafy vegetables. Young, green uncultivated leaves were cooked in salted water for a short period and, according to Jones (1963:81), the water was not drained off. When the relish was cooked, it was beaten to a smooth consistency and sometimes flavoured with legumes or peanuts.

Almost all foods were boiled for a short period (Jones, 1963:81). Jones observed that only the coarser green European vegetables such as cabbage or spinach were boiled for lengthy periods. Certain cuts of meat and green mealies (maize cobs) were roasted next to the fire. Jones (1963:81) reported that frying was a more recently introduced cooking method, especially in urban areas where fried meat, onions and tomatoes formed the basis of a stew. Baking, a modern way of food preparation for the Swazis in the 1960s, took place in iron stoves or in ant heap ovens (Jones, 1963:81).

The case study indicated that acculturation had taken place with respect to food preparation (Kgaphola \& Viljoen, 1999). Both traditional and Westernised cooking methods and dishes were used. The most common cooking methods were boiling, stewing, frying and roasting. All green leafy vegetables were boiled in salted water. All the participants reported using bicarbonate of soda when cooking one indigenous leafy vegetable called igushe. Aloe ash was traditionally used (Ogle \& Grivetti, 1985a). The use of bicarbonate of soda was also reported for cooking other leafy vegetables, especially when the leaves were not tender. It was common practice to add tomatoes or potatoes and/or onions and fat to leafy vegetables such as spinach and cabbage. When pumpkin leaves were cooked, tender green pumpkin fruits and the flowers were boiled together, and ground peanuts were added just before the water dried up.

Legumes were boiled, and fat, onions, tomatoes and flavouring were added when the legumes was soft and tender. Beans were sometimes cooked with soup bones (shin). Boiling, stewing, roasting or frying were used as cooking methods for meat. On Sundays a chicken was either roasted or fried in deep fat. Fresh 
fish was fried, and tinned fish was cooked in fried onions and tomatoes. Eggs were either boiled or fried. Baking and steaming were sometimes used for scones and dumplings respectively. Westernised cooking methods had therefore clearly been introduced. The use of fat and oil in food preparation seemed to have increased (Ogle \& Grivetti, 1985a).

Beemer (1939), Jones (1963:80-81) and Ogle and Grivetti (1985a) reported that Swazi food preparation techniques were very similar to those of other black ethnic groups in Southern Africa (Coetzee, 1982:121122). Due to the available technology, these food preparation techniques were time-consuming. Before the meal could be prepared, firewood had to be collected and water fetched. The women had to walk long distances to collect firewood and water. Cooking utensils had to be washed before meal preparation could begin. Cold water, sand, ash or fine stones were used as abrasives (Jones, 1963:80). Technology therefore had a considerable impact on Swazi food habits.

\section{CONCLUSION AND RECOMMENDATIONS}

Due to the sample size, the findings of the case study cannot be generalised for all Swazi households. However, valuable information was collected on current food habits among rural Swazi-speaking households. The case study found that technology definitely had an impact on the food habits of the ten rural households in the study. The influence of technology was also evident in the availability of storage, preservation and preparation techniques. Although the physical availability of food was influenced by economic factors, the participants did report that they were unable to buy perishable foods because they had no access to cold-storage facilities. They had to rely on tinned foods that were not always the preferred choice. Furthermore, a large quantity of food was prepared once during the day and leftovers were served in the evening to save wood.

It is evident from the findings of the case study that acculturation had taken place in terms of the food habits of the participating households. None of the participants maintained typical traditional Swazi dietary patterns, and current patterns could be described as a combination of traditional Swazi and Western dietary customs. Western cooking methods such as frying, roasting and baking had been adopted.

Since food preparation methods can either improve or decrease the nutritional value of food, nutritionists will have to identify and promote the positive aspects of both traditional and Western cooking methods and discourage the negative aspects. The addition of ground peanuts, potatoes, tomatoes, onions and fat increased the nutritional value of a vegetable relish, whereas the addition of bicarbonate of soda reduced it.
Despite the apparent acculturation, the food habits of the participating Swazi households still resemble traditional Swazi food habits. Indigenous crops and uncultivated foods still play an important role in the Swazi diet. This suggests that culture has an extensive bearing on the food habits of rural Swazi households. Food security projects should therefore be sensitive to traditional value systems to ensure relevance and effectiveness. Traditional foods and food sources should therefore be integrated in such projects.

Technology has a considerable impact on food habits. It provides the means by which the environment is exploited to meet human needs such as food. Technology promotes the availability of food by ensuring optimal food production, storage, preservation, transport and utilisation. Technology can alleviate the burden of rural women in processing and preparing food and is therefore crucial to household food security programmes.

\section{REFERENCES}

BEEMER, H. 1939. Notes on the diet of the Swazi in the Protectorate. Bantu Studies September:199-236.

COETZEE, R. 1982. Funa food from Africa. Roots of traditional African food culture. Pretoria. Butterworths.

DE GARINE, I. 1972. The socio-cultural aspects of nutrition. Ecology of Food and Nutrition 1:143-163.

FIELDHOUSE, P. 1995. Food and nutrition: customs and culture. 2nd ed. London. Chapman \& Hall.

HAMILTON, JA. 1987. Dress as a cultural sub-system: A unifying metatheory for clothing and textiles. Clothing and Textiles Research Journal 6(1):1-7.

JEROME, NW, PELTO, GH \& KANDEL, RF. 1980. Nutritional anthropology. New York. Redgrave.

JONES, SM. 1963. A study of Swazi nutrition. Durban. Institute of Social Research, University of Natal.

KGAPHOLA, MS \& VILJOEN, AT. 1999. A case study on the description of the food habits of ten selected rural Swazi households at Ka-Mantsholo between Badplaas and Barberton (Mpumalanga). Unpublished. University of Pretoria.

McINTOSH, EN. (1995). American food habits in historical perspective. Westport. Praeger.

OGLE, BM \& GRIVETTI, LE. 1985a. Legacy of the chameleon: edible wild plants in the Kingdom of Swaziland, Southern Africa. A cultural, ecological, nutritional study. Part I. Ecology of Food and Nutrition 16:192-208.

OGLE, BM \& GRIVETTI, LE. 1985b. Legacy of the chameleon: edible wild plants in the Kingdom of Swaziland, Southern Africa. A cultural, ecological, nutritional study. Part II. Ecology of Food and Nutrition 17:1-30.

OGLE, BM \& GRIVETTI, LE. 1985c. Legacy of the chameleon: edible wild plants in the Kingdom of Swaziland, Southern Africa. A cultural, ecological, nutritional study. Part III. Ecology of Food and Nutrition 17:31-40.

POPENOE, D. 1986. Sociology. 6th ed. New Jersey. Prentice-Hall.

SOEMARDJAN, S. 1985. Influence of culture on food and nutrition: the Indonesian case. In Biswas, MR (ed). 1985. Nutrition and development. London. Oxford University Press. 